\title{
Science stories, Life stories: engaging the sciences through feminist science fiction
}

\begin{abstract}
Despite the groundbreaking work of feminist science scholars, the 'two culture' divide between the science and humanities remains pronounced in feminist scholarship. As critics such as Elizabeth Wilson and Vicki Kirby have observed, much feminist philosophy fails to engage with scientific understandings of 'life' in their accounts of gendered subjectivity and embodiment. One area where feminist work in both the sciences and the arts may be seen to productively converge is in feminist science fiction (SF). This article argues that feminist SF could be a vital participant in 'cross-cultural' feminist conversations about the cultures and discourses of the natural sciences, through a close reading of the 2004 novel Life, by Gwyneth Jones.
\end{abstract}

As a feminist scientist, one of my goals is to demonstrate not only how certain theories in science can help to expand and deepen feminist theory, but also to demonstrate how feminist theory can provide scientists with creative resources for rethinking the kinds of questions that they ask and the answers that they find.

(Weasel, 2001, pp. 28-29)

The last four decades have seen an increasingly complex and productive exchange between feminism/s and the sciences, encapsulated by the emergence of feminist science studies as an identifiable field of enquiry. The work of critics such as Elizabeth Wilson, Karen Barad and Myra Hird signal the increasingly productive exchanges occurring across the "two cultures” divide, and reinforce Weasel's belief that such dialogues are important, even crucial, for feminist theory. This article investigates the potential of a little-noted, yet uniquely placed resource for such “cross-cultural” dialogues, namely science fiction (SF) literature. Despite its lack of cultural cachet, and less than significant profile outside the SF field, feminist SF has, I argue, the potential to be just the kind of "creative resource” Weasel talks of, for both feminism and the sciences. The notion that SF might have something to offer feminist thinking about such issues is not new. Donna Haraway has often singled out feminist SF as a useful tool for thinking differently about stories of science, most famously in her "Manifesto for Cyborgs” (Haraway 1989; 1991; 1995). Another prominent science critic, Hilary Rose has offered similar arguments: “feminist science 
fiction is a major cultural intervention within the politics of science and must be considered in that light” (Rose, 1988, pp. 377-8).

Twenty years later, few have followed Haraway and Rose’s lead in viewing feminist SF as a space of productive convergence between the arts and sciences. Even within the specialised field of feminist SF criticism, there exists a similar lacunae; most studies to date are firmly grounded in literary criticism with surprisingly little attention paid to the role of the sciences in feminist SF. ${ }^{1}$ SF remains an underutilised resource in thinking through some of the problematics of two-culture engagements, perhaps precisely because of its hybridized positioning on the twoculture border.. In contrast, artistic encounters with science such as bio-art are routinely singled out for their ability to go beyond critique or simple engagement with the sciences. Yet the ability to "work with the very apparatus, techniques and materials of scientists" is also available to SF writers, whose ranks include a significant number of scientists, and many more amateur researchers who, like artists, do indeed "go into laboratories” as part of their research (Mackenzie \& Murphie, 2008, p. 97).

Given that few feminist SF texts are likely to be familiar to a general audience, in this article I focus on just one example, the 2004 novel, Life by British author Gwyneth Jones. Life provides a good introduction for feminist readers who might find distasteful such SF tropes as spaceships and aliens, as such conventional icons are entirely absent from the novel. (Indeed Life was rejected by many SF publishers for being “too mainstream”.) More importantly, Life is a vital, challenging, and complex example of feminist fiction that can draw on its generic positioning and history to "boldly go" where few realist fictions can. In other words, feminist fiction like Life can, as Haraway and Rose have argued, be a useful critical tool for feminist interactions with the sciences. In particular, Life speaks to two related, although quite distinct, concerns in contemporary feminist engagements with the sciences: the nature of women's work in the 
sciences, and the integration of the biological and material into our theorisations of sex and gender.

\section{Feminist SF and science studies}

In many ways feminist SF occupies the same uncomfortable discursive and cultural space as science studies itself - an un-easy balancing between the two cultures of science and the humanities. Whilst feminist studies of science often employ humanities-based methodologies to examine and critique science, SF can draw on both literary techniques and the language and methodologies of science: creating potentially boundary-crossing “fictions of science”. Like many critics in the field of feminist science studies, some SF writers are originally scientists whose feminism impels them to write different stories. In science studies, for example, we have Haraway, Karen Barad, and Lisa Weasel; in SF authors such as Joan Slonczewski, Vonda McIntyre and Julie Czerneda. And like many humanities-trained science critics, SF authors are often avid “amateur” readers and researchers of science, including Jones herself, Nancy Kress, Kathleen Ann Goonan and Nicola Griffith. Such authors share with feminist scientists and science critics a fascination for, and even love of, science. Like Weasel, a feminist biologist, they share the impulse to "both critique and find inspiration with science’s bounds" (my emphasis, Weasel, 2001, p. 28).

Whilst feminist critics can highlight new questions to pose of the epistemology and methodology of the sciences, (Weasel, 2001, p. 29) the imaginative space of feminist SF might be better positioned to articulate different questions about science and gender. In contrast to science studies (with the possible exception of Haraway) SF is freer to “play” with the languages, cultures and futures of science: for example, to try and imagine a "feminist science" in a context where the cultural constraints of the contemporary scientific establishment do not render this question difficult, if not impossible to answer. As Jones herself comments, when engaging with a 
scientific text such as Short and Balaban's The Differences Between The Sexes (1994), she does not have to apologise for reading it politically; or for providing her own imaginative interpretations of the "purely descriptive". On the contrary, Jones says she is "looking for hooks and riffs; material [she] can use”: or indeed "misuse”, rather than concepts to be analysed or deconstructed (1999, p. 104).

SF writers then, might engage with or read science not like "scientists" or even scholars of science. They are not necessarily looking for biases to be uncovered or cultures or practices to be extrapolated but material to be used, revised, re-interpreted. Thus writers like Jones can, if they wish, bypass the process of deconstruction and critique and engage directly in reconstruction. They can rewrite the experiment, produce different results, have it "prove” something entirely different. In this sense, SF writers may be engaged in a similar endeavour to that of Weasel; looking "beyond simply critiquing science” to "identifying examples of science that might serve as critical resources for re/constructive feminist projects in the sciences” (Weasel, 2001, p. 28). The SF writer's ability to extrapolate or re-vision an entirely different context within which certain scientific facts, discoveries or trends are played out, points to yet another role they can play as "aide” to science studies. SF can postulate an alternative to the cultures, and practices of "science-as-usual”, and render more vividly the resulting (or required) changes in the interpellated areas of scientific cultures, theories and practices.

Finally, as Haraway has pointed out, the very generic positioning and reading protocols of SF make such texts invaluable aids to the kinds of altered, irresponsible and in/appropriate(d) stories that she likes to tell with and about science.

SF conventions invite - or at least permit more readily than do the academically propagated, respectful consumption protocols for literature - rewriting as one reads... Because SF makes identification with a principal character, comfort within the patently constructed world, or a relaxed attitude toward language, especially risky reading strategies, the reader 
is likely to be more generous and more suspicious - both generous and suspicious, exactly the receptive posture I seek in political semiosis generally. (Haraway, 1992, p. 326)

Drawing on SF writer Ursula Le Guin, Haraway advocates a "carrier-bag practice of story telling” (Haraway, 1995, p. 71). Like Le Guin, Haraway wants stories which “do not reveal secrets acquired by heroes pursuing luminous objects across and through the plot matrix of the world. Bag-lady story telling would instead proceed by putting unexpected partners and irreducible details into a frayed, porous carrier bag (1995, p. 71). Often, in her feminist science storytelling, these partners include science fiction, and the carrier bag is labelled "SF": a signifier for a complex altered field, which contains both speculative fictions and scientific facts (Haraway, 1989, p. 15). For Haraway, SF's use lies not just in the ways it produces different perspectives on "other" science stories but also because it aids the development of "multiple literacies" and "diffractive reading” that is so crucial to her critical practice (Schneider, 2005, p. 149).

With this necessarily brief overview of some of the ways in which feminist SF performs serious cross-cultural work, I turn now to the specific example of Life.

\section{Life in the lab - a woman doing science}

Jones has written a number of challenging, insightful and blackly humorous feminist SF novels, beginning with Divine Endurance in $1984 .^{2}$ All of her works are intimately concerned with the relations between gender, sex, power and knowledge and how such relations impact on our interactions with, and constructions of, nature. This focus emerges from Jones' fascination with "the naked equations of sexual difference" and her drive to "investigat[e] the causes of the battle of the sexes” (Jones, 2008, p. 2007). Life is the result of many years of such investigations, influenced by sources such as The Differences between the Sexes (Short \& Balaban, 1994) and 
Evelyn Fox Keller's A Feeling for the Organism (1983). Set in a near-future Britain, the story of Life focuses on the biologist Anna Senoz, from her early university days through her various experiences of study, career, relationships and sexual encounters. Central to Anna’s story are those of her partner Spence, a house-husband and children's book author, and their sometime friend the shocking “post-feminist” author Ramone Holyrod. Crucially, Life is also the story of Anna’s great discovery: what she calls “Transferred Y” (TY). TY describes a phenomenon whereby sections of the sex-determining region (SRY) of the Y chromosome are transferring over to the X chromosome, apparently effected by a virus. In Anna’s words, What the TY viroid did was to snip a specific piece out of the Y and paste it into a specific site on the $\mathrm{X}$, in a human male. Once this has happened, and been inherited, the $\mathrm{X}$ and $\mathrm{Y}$ start to reshuffle, and in a generation or two, the $\mathrm{Y}$ becomes indistinguishable from a second X, with male-determining genes. (p. 359) There are a number of ways in which Life invites useful reflections on the current state and direction of feminist engagements with science, particularly the tension between the focus on institutions and methods characteristic of practising feminist scientists (see, for example, Roy, 2004; Wayne, 2000), and humanities-based analyses of the gendered nature of scientific discourse and epistemology. The growing sense of the inadequacy of empiricist campaigns to add more women to "science as usual” has its downside: on what basis do we encounter the continuing practical issues of how to deal with women's uneasy, marginalised position in the sciences? Whilst not endorsing either empiricist claims or a limited standpoint notion that science can be “fixed" by encompassing women-centred knowledge, Life usefully re-focuses on the persistent problem of how to “do” science as a woman. It also suggests that, particularly when dealing with the biological sciences, the stories we tell about genes, evolution, and sex chromosomes exist in a complex relation to assumptions about the impact of the sex/gender order on the practice of science. 
For feminist scientists there are obvious connections between epistemological androcentrism, and the everyday lab cultures of conflict, competition and petty sexism, which are deserving of closer attention (Wayne, 2000, pp. 139, 143). In Life, the well-known obstacles of being a female scientist in these environments are starkly revealed through Anna’s (mis)fortunes. On the surface, Anna would appear to be perfect scientist material for, despite being a woman, Anna is in many ways coded as masculine. In contrast to her husband Spence (who is the homemaker, lover, writer, emotional partner), Anna is the driven scientist and primary wageearner who is logical, “cold”, a “vulcan”. However, Anna’s performance of these masculine roles is not enough to protect her from the institutionalised gendering of scientific practices, norms and codes. For ultimately, it is she, not Spence, who has the biological misfortune of being the sex that gets pregnant (and raped) and is consequently treated like a second-class citizen in her undergraduate career, in her doctoral placement, her eventual career in "baby-pharming" for the company Parentis, and in the global scientific publishing community. The varied scenes of Anna’s disappointments and marginalisations signals the complexity of meanings aggregated around the notion of “doing science”.

Jones presents an unusually detailed account of the minutiae of life as a career scientist, highlighting the multitude of processes, institutions and hierarchical practices implicated in the production of a scientific “fact” (Roy, 2004). Anna’s long and troubled path to eventual infamy brings into sharp relief the complex issues of knowledge dissemination, peer review, publication, and reproducibility essential to the production of science. The hierarchical and phallocentric nature of these processes are highlighted in Life through the dismissal of Anna's early papers on TY and the marginalisation of her second doctoral supervisor, Clare Gresley. Gresley’s theory of continuous creation has effectively ended her academic research career, leaving her to make a living as a commercial supplier of viruses for others' research (pp. 139-40). There are obvious references here to path-breaking female scientists such as Barbara McClintock or Lyn Margulis, 
whose challenges to science-as-usual were similarly met (at least initially) with suspicion, if not downright ridicule and hostility. Such parallels are not accidental. As Jones details in a chapter on the writing of Life, her research on genetics encompassed those "heroes of the resistance" like Margulis and McClintock who challenged the notion that "[e]very organism, every gene, was an isolated warrior, forging alone through the ages, ruled by arbitrary fate” (Jones, 2008, p. 21). ${ }^{3}$

Life is intensely interested in what it means and what it costs to be a "woman in science", whilst simultaneously subjecting scientific stories of "life" to a feminist interrogation of how such understandings intersect and conflict with our gendered social order. The novel offers an image of a female scientist who accords with empiricist beliefs about the meritocracy of science. Anna’s "success”- the discovery of Transferred Y results from her dedication to detail, improving methods, being meticulous, and inquisitive; in effect being a "better scientist" than many of her colleagues or employers want her to be. Her passion for "pure" science leads her to be resistant to the "bias" of her employer, Parentis, with its focus on male fertility that is the guiding force of much sex-chromosome research in the book - a bias which would lead others (like her co-worker Sonia) to ignore the "anomaly" of the TY effect.

However Anna's ongoing experience of marginalisation and discrimination are forcefully and painfully detailed in the text. Her particular positioning in science and thus the restraints placed on her scientific practice emerge because she is a woman, not because she is an inferior scientist. Significantly, two of the key experiences which come to delimit and define her career confront Anna the scientist with the lived reality of life in a woman's body. In her final undergraduate year, she is raped by fellow student Charles Craft, just after discovering he has submitted her research as his own for their joint final project. Her emotional and political inability to reveal either of these attacks almost destroys her career before it starts - robbing her of the first class degree and postgraduate position her work had entitled her to. Later her first pregnancy and eventual motherhood severely circumscribe her career options and impact on the 
way she is perceived by her colleagues and supervisors. Yet Anna continues to cling to the ideal of a scientific meritocracy, and to believe in an idealised, gender-neutral pursuit of scientific knowledge. Whilst we may read against Anna's position in emphasising the importance of gender in these events, the book does not endorse a simplistic notion that there is a "woman's way" of doing science. Anna's eventual infamy and discovery do not result from her being a woman per se, rather (as Fox Keller comments of McClintock) the relevance of gender here is "to be found not in its role in her personal socialization but precisely in the role of gender in the construction of science” (Fox Keller, 1985, p. 174; see also Weasel, 2001, p. 38).

In combining a detailed picture of a woman doing science with a feminist perspective on the gendered nature of scientific cultures and institutions, Life begins to address some of the concerns of working feminist scientists, even though it cannot offer a "concrete feminist model of scientific enquiry” (Roy, 2004, p. 256). However, it certainly meets Weasel’s goal and does more than just critique science, it actively engages with biological theories, and draws upon this science to reflect on that primary concern of feminist theory: the relation of sex and gender.

\section{Of Chromosomes and Cultures: the Biology of Life}

With its central focus on the science as well as politics of “Life”, Jones' novel shares the critical impulse to address the sciences seen in feminist science studies. As Haraway argued back in 1978,

we have allowed our distance from science and technology to lead us to misunderstand the status and function of natural knowledge ... We have challenged our traditional assignment to the status of natural objects by becoming anti-natural in our ideology in a way which leaves the life sciences untouched by feminist needs (Haraway, [1978] 1991, p. 8)

Indeed the last three decades have seen many such warnings from feminist critics concerning the dangers for feminist theory in disregarding or marginalising biology: "it remains inadequate (both 
theoretically and politically) for feminism simply to reject the biological” (Roberts, 2000, p.1; see also Severin \& Wyer, 2000; Wilson, 1999; Kirby, 2008). The consequences for such dismissal are seen both as an increasing vulnerability following the fallout of the science wars (Schneider, 2007, 148), and also as epistemologically unproductive, given the turn in many life sciences to understandings which actually work against traditional dualistic binaries such as the mind/body split (Kirby, 2008, p.7; Hird, 2004a).

Myra Hird's work, for example, highlights the importance for feminist theory of developments in “new materialism”, which ranges from non-linear biology (for example, Margulis \& Sagan, 1997), to the work of critics such as Manuel De Landa and feminists Elizabeth Grosz and Elizabeth Wilson (Hird, 2004b). Wilson's exemplary study of cognition, for example, "brings together cultural and scientific understandings of the brain behaviour" (Hird, 2004b, p. 224). For Wilson, resistance to the sciences or an "antibiologism” rests on untenable separations between "the static and the changeable, the natural and the political, the chromosomal and the cultural” (Wilson, 1998, p. 200). In challenging such divisions, new materialism “offers analyses that confound the often taken-for-granted immutability of sex and sexual difference found in some cultural theories" (Hird, 2004b, p. 231). Life also confounds, if not shatters, this “immutability of sex and sexual difference”, providing another potential example of new materialism. And like Wilson's text, Jones' novel refuses the easy division of the natural from the political, or the chromosomal from the cultural. Just as the title encompasses both symbolic and material meanings, the novel operates through a complex doubled narrative that relies on the "interimplication” of biology and the social. ${ }^{4}$ Not only are we reading the "life story" of Anna, Spence and Ramone, but also a parallel evolutionary narrative about organic life - that is, a story of chromosomes as well as cultures.

Life encourages and facilitates feminist engagements with the natural sciences on a number of levels, from providing complex reflections on the possibilities of non-linear biology, 
to the simple tactic of directly utilising scientific concepts and language It presents, unusually, a literary feminist text which deliberately employs the language of molecular biology, beyond simple references to the familiar sex chromosomes, to the use of specific, technical language for describing the function and behaviour of cells and theories of biological change and evolution. As a humanities-trained feminist reader I was challenged to think through and understand this language, and indeed was inspired to go away and conduct my own research in an effort to comprehend Anna's scientific explanations more fully. At a crucial point in her research, Anna is discussing a modelling scenario run by AI computer nicknamed Suri:

“That’s SRY,” Anna said shortly: touching the model with her wand to home in on the code she could not mistake. "The testes-determining gene. And SDF, and SDF2. Some of these Xs are males Xs! This is like, the fertile XX males we've been seeing in the clinics!”

"As you know," said Suri, “we believe the mammalian Y chromosome was formerly another X, differing only in a few sex-determining genes. It looks as if the TY viroid is going to restore that state. On our current estimates of TY occurrence in the population, the human Y chromosome could, effectively, disappear in a few generations.” (p. 199). ${ }^{5}$

As my amateur research revealed, this development was based on real-world science which predicted the eventual "descent of man" based on the deterioration (and perhaps disappearance) of the Y chromosome - but on a much slower time scale: "At the present rate of decay, the Y chromosome will self-destruct in around 10 million years” (Aitken \& Graves, 2002, p. 963). ${ }^{6}$

On another level, Anna's positioning encourages a feminist reflection on the practice and theory of the science she loves. As a feminist reader I read against her own, internalised, "genderneutral" understanding of events such as the rape, the reaction to her first pregnancy, her 
supervisor KM Nirmal’s reaction to her “maiden speech” and other obstacles in her scientific career. The potential dangers of bringing a feminist sensibility to bear on biological theory (as noted by biologists such as Roy and Wayne) are made evident through Anna’s resistance to even downright distaste for - the "messy" sexually-politicised ramifications that she rightly fears TY could provoke.

TY is about sex, and that means trouble. Worse than Continuous Creation, even.

There are significant people in life science who would react very poorly, although they'd never admit they were personally upset about the daft "death of the male Chromosome” aspect (p. 206).

For the reader (if not, initially for Anna), Life suggests an important corrective to one of the key problems identified by feminist and social studies of science - the decontextualisation of the subject of study. In molecular genetics, for example, Anne Fausto-Sterling argues that the organism and egg cells are "literally and conceptually decontextualised” (2001, p. 236). In the novel, the study of chromosomes, the practice of science and the very narrative of TY are firmly enmeshed in the broader context of “life”. Anna’s study, practice and theorising are intimately intertwined with and contextualised by the narrative threads of her personal life: her family, friendships, and non-research work. Unlike her boss, Nirmal, Anna’s struggle to build a scientific career as a woman makes clear the feminist realisation that "domestic arrangements are part of the culture of science”, hidden or un-acknowledged though they may be (Schiebinger, 2001, p. 93).

Similarly, throughout her career Anna is increasingly drawn to non-traditional theories of genetics and evolution: theories often championed by female scientists and feminist critics. Throughout the book, it becomes clear that Anna's discovery is influenced, even inspired, by her increasing resistance to masculinised Darwinian accounts of evolution, and a growing openness to theories of change that emphasise cooperation and interconnectedness. Early on she makes 
reference to (Mooto) Kimura whose "neutral theory of evolution” de-emphasises the role of natural selection in genetic variation. Although Kimura's (real world) theory is not necessarily viewed as incompatible with Neo-Darwinism, Anna employs it as a preferred, alternative evolutionary explanation: “At the nucleotide level, there’s no Darwinism, not what people think of as Darwinism, not at all” (p. 67).

A sub-textual critique of neo-Darwinism emerges with Anna’s growing distance from accepted theories of evolution. Anna’s second supervisor, Clare Gresley is marginalised from the scientific community because of her “doomed” pet theory, “continuous creation”, which emphasises “natural communication and commerce between all living organisms” (p. 146). Anna is at once pitying and aghast at Clare's situation - doomed to obscurity by the scientific establishment because of her wrongheaded tenacity in clinging to her theory. Yet Clare’s focus on "infectivity" proves to be the key to the TY effect; and by the end of the novel, Anna has proposed a new version of Gresley’s theory in the “Aether”, which situates the TY phenomenon as "pointing the way to a new paradigm of life science that saw all species as nodes in a continuous fabric of living particles, viroids, prions, viruses ... interacting with each other constantly, positively, at the nucleotide level” (p. 279). There are clear connections here with the work of “pioneers” such as McClintock and Margulis. In particular it resonates with Margulis’ Serial Endosymbiosis Theory, a "symbiotic, cooperative view of biological change [which] presents a very different model from the Darwinian and neo-Darwinian competitive view” (Williams, 2007, p. 133). Importantly, for the convoluted discursive and material meanings which distinguish our understandings of sex and gender, in such theories "organisms are seen as combined, invaded and changeable” (p. 133).

\section{The science of Life: tool for feminist critique?}


Biology is the fiction appropriate to objects called organisms ... Organisms perform for the biologist, who transforms that performance into a truth... into a fact ... Both the scientist and the organism are actors in a story-telling practice (Haraway, 1989, p. 5)

Thus the science in Life is important not only for its presence but for its part in the novel's approach to sex, gender and biology. Transferred $\mathrm{Y}$ is a crucial part of the narrative that, just as much as the story of Anna's life, is used to interrogate our understandings of sex and gender. The centrality of this biological narrative prompts consideration of whether the "imagined" biological science represented in Life might function as the kind of feminist tool that many feminist scientists are struggling to construct. In other words, the novel might exemplify Weasel's wish that the sciences could be drawn upon to critique and contribute to feminist theory, and not just the other way around.

The TY viroid can be read as challenging a number of normalised understandings about sex, biology and gender from both scientific and non-scientific perspectives. This device enables the text to highlight the crucial instabilities and contradictions at the heart of the binary sexgender imbrication. The moral outrage following confirmation of the already widespread effects of the TY viroid signifies the tenaciousness of the model of sexual dimorphism as a "natural" structuring element of society. The TY viroid not only turns renders this model invalid, or "disappears” one sex, but subsumes "man” into "woman”. By the end of the book, increasing numbers of men -- including Spence and (ironically) the ultra-patriarchal Charles Craft -- are found to be XX males. Thus the normative system coding sex chromosomes as biological markers of "sex-species" is rendered irrelevant. Men are not turning into women, but are just men who no longer have a Y chromosome: men who no longer have the essential "difference" that, in the language of science, cleanly and irrevocably marks them as separate from women. As Ramone gleefully comments, “Men become women with dicks!” Anna replies: “Or women become men with tits. You can make the words do anything you like” (p. 359). For Anna, this 
breakdown of the male-female distinction is not surprising, nor even very disturbing to her understanding of sexual difference.

In nature, before any of this started, many people were sexual mosaics, whether they knew it or not. In time, TY may create a situation where there are no genetic traits exclusive to "men” or "women”: when sexual difference is in the individual, not a case of belonging to one half of the species or the other (p. 362).

The separation of humans into two distinct "sexual species" does not predate and ordain the twogendered social system but is itself structured by the assumption of the simple binary male/female. Such views are becoming commonplace in non-linear biology, as Myra Hird points out,

”sex" is not dichotomous. It makes as much sense, biologically speaking, to talk about zero sexes (we are much more similar than we are different) or a thousand tiny sexes ... That culture focuses on two sexes is, biologically speaking, arbitrary (Hird, 2004a, p.151).

Anna's struggles in her scientific career reinforce the message of her earth-shattering, yet strangely uneventful, discovery that biological "sex difference” is ultimately irrelevant. It is the cultural hierarchies and differences we have mapped onto the XY human sexual difference that really matter, that persist. (And would persist, Life predicts, even if the "Great divide” as marked by our sex genes ceased, overnight, to exist.) As Veronica Hollinger notes (of the story "Balinese dancer”), the "real impact of Anna’s discovery lies in the implication that sexual difference, one of the foundations of human life, is transitory” (Hollinger, 2006, 331). The operations of the TY viroid serve to reverse the usual assumptions of cultural critique which hold that the material is fixed and unchanging, while the cultural is in flux and thus open to intervention. In Life the material is the location of radical flux whilst it is the social and cultural arenas which remain 
stubbornly unchanged. In this way, Life pursues a similar trajectory to the work of critics like Kirby and Hird:

It seems to me there are current and future debates within feminist theory that might productively engage with materiality, and I see in the general shift toward "neomaterialism" a desire to formulate new questions for feminism. For instance, we may no longer be certain that it is nature that remains static and culture that evinces limitless malleability, and feminist theory may want to look at the ways in which we divide culture from matter on the assumption that matter is unchangeable (for instance, in formulations that accept the sex/gender binary) (Hird, 2003, 4.2; see also Kirby, 2001, p. 54).

Not surprisingly then, the importance of TY lies primarily in what it provokes in terms of cultural reception. The existence of the TY viroid is gradually, albeit reluctantly, accepted by the scientific community almost without fanfare:

The life science and human genetics establishment didn't ignore her, but they went straight from the position where Transferred $\mathrm{Y}$ was an outrage that could not possibly exist to yeah, TY exists, and so what? Cunning bastards (p. 262).

It is not until reports that the TY viroid has already affected a wide sample of the population are confirmed that both scientific community and public opinion explode.

In the end, what is really shocking about TY is its revelation that the "difference" that both codifies and justifies human sexual differentiation has always/already been eroded. The question that emerges is how to reconcile the disappearance of that internalised and naturalised divide with an apparently unchanged social order structured by this distinction. Of course, these cultural roles have already started to shift - and here the novel teases us with the notion that perhaps it was TY all along that was responsible for the kinds of societal change which, for example, allowed Anna to be a woman and a scientist: "it must have been the TY effect that had made Anna like that, 
given her the puzzle of being a woman and a scientist” (p. 334). Certainly we are encouraged to read Spence as a “woman with a dick”. On the other hand, Charles Craft -- Anna’s university nemesis, rapist and thoroughly unreconstructed patriarch - is also revealed to be an XX male. So this is not a simple causal link between sex and gender functions, or a metaphorical role reversal. Instead, the realities of the chimerical nature of biological sex and its complex expression through culture are foregrounded in the shifting and multiplex sexualities, appetites, behaviours and appearances of the main characters. Spence, in particular, acts as a caution against assigning roles based on rigid understandings of the sex/gender division. Spence does not accord with typical male stereotypes; from early on in the novel, he begins "to suspect that there was something out of kilter about his maleness” (p. 40). His lack of conformity to the usual male sexual stereotypes is reinforced over and over again: the influence of his feminist, hippy mother; his lack of attraction to most girls; his peers’ assumption he is gay; his androgynous physique; his sexual fantasies around wearing Anna’s underwear and lack of “domineering” characteristics. Balancing these "feminised" traits are the facts of his obvious and physical sexual attraction to Anna, and his flirtation with an extra-marital affair. Between them, the characters of Spence, Anna and Ramone reinforce the notion that a simplistic oppositional, dualist correspondence between sex and gender is ridiculous:

The idea that gender is all-important could be simply wrong. Down among the chromosomes, the science is neutral. Every human body (right now, no fantasy intervention required) is a mosaic of male and female cells. The whole idea that humanity is divided into two halves could be a chimera. One day it could just vanish, like the Cold war, like the crystal spheres, like canals on Mars and jungles on Venus (Jones, 2008, p.301).

So without the definitive XY code to naturalise and over-determine the "difference between the sexes” and underwrite gender, what is left? Life's answer would seem to be, nothing 
- and everything. On the level of general population, or the cellular level there is no useful difference to be perceived - in the end, "sexual difference, like genetic difference, is individual" (Jones, 2005). Ultimately, then, Life carries the seemingly contradictory message that we must engage the biological sciences in order to escape biology, or at least essentialist and determinist notions of biology. Only then might we come to the quite different realisation that "the problems between men and women are not biological, they are moral” (Jones, 2005a).

\section{Learning from Life}

Thus Life, like the writings of new materialist feminists, suggests that we can only really deal with the cultural implications of our gendered social system once we stop seeing chromosomes, matter or "nature" as being somehow outside, and separate from, this cultural system. Like advocates of the new materialism such as Hird, Life reminds us that "while nature emphasizes diversity, culture emphasizes dichotomy", and illustrates why the use of biology "to reify sex dimorphism" should not deter feminists from seeing the natural sciences "as a useful site for critiques of this dichotomy” (Hird, 2004a, p. 152). At the same time, the whole novel and its title can be read as a reminder that the conception of "life" offered by the dominant narrative of molecular biology (or what Jones terms "Stupid Darwinism”) is narrow and reductionist (Jones, 2007). As originary story, such concepts alone cannot explain or represent the complexity, interimplication or "complementarity" of the biological, social and historical relations between humans and non-humans, on a variety of levels, from molecular and cellular to societal (Spanier, 2001, p. 283). In its unusual focus on the social relations and cultural contexts of science, Life provokes useful reflections on the issue of women and/ or gender in science - pointing to the continued importance of interrogating the institutions of science. The still-present gulf between humanities-trained science studies scholars, and practising scientists (ironically referenced through the tumultuous relation of Anna and Ramone) suggests the need to continue dialogue 
across the two cultures not just concerning epistemology and methodology, but also the politicised institutionalisation of disciplines.

Life also mirrors an emerging scepticism about the continuing political and epistemological salience of "gender" as the pre-eminent critical tool of feminist analysis. ${ }^{7}$ For example Anne Fausto-Sterling has called for a reconsideration of "the 1970s theoretical account of sex and gender", which "assigned biological (especially reproductive) differences to the word sex and gave to gender all other differences” (Fausto-Sterling, 2005, pp. 1495,1493). ${ }^{8}$ Divorcing feminism from gender is a big ask, for feminist critics as much as feminist SF readers. For me, reading books like Life, alongside critics like Haraway, Fausto-Sterling, Wilson, Kirby and others, leads to an inevitable questioning of the continuing value of feminist theory's "useful category”, gender. Texts like Life might help us think through how feminist theory and praxis can proceed in a world (and discourse) without gender. A world without gender like the one hinted at in Life: populated by men and women, and still troubled by "sex", rather than the "genderless" or androgynous utopias and/or dystopias this phrase has usually suggested for second-wave feminists. (The alternative might be uncomfortably close to the situation Jones describes in her Aleutian series: that of a "gender war - not wars between men and women, but between people who believe in gender and people who don't” (Jones, 2005b).)

Finally, in its emphasis on competing and multiple selves, relations, ways of being and ways of theorising "life", Life provides a useful space from which to reflect on the contemporary state of the feminist science studies field. Recently, Margret Grebowicz has criticised what she sees as a trend to measure the success of feminism in science in terms of its constructive contribution to "science as usual". In her view, we have become too concerned with emphasising how feminism may have improved "particular, existing scientific enterprises, both epistemically (truer claims) and politically (more democratic methodologies and applications)” (Grebowicz, 2005). As Grebowicz argues, Haraway warned us long ago of the dangers of feminist research 
which “tells 'of a different human nature, of different universals' but fails to 'leave the traditional space of science’” (2005, citing Haraway, 1991). The feminist efforts to redefine objectivity in science have, Grebowicz believes, come adrift from the feminist innovation of "dissensus ... as the alternative to epistemological models which rely fundamentally on consenses as the telos of critique” (Grebowicz, 2005). Whilst critics such as Helen Longino have recognised the importance of allowing for “different groups and individuals with ... different stakes” in science, a dissensual approach accepts the irreducibility of these differences (Grebowicz, 2005; Longino, 2002). A “dissensual critique-model” of science studies then, starts “from the assumption that contest and polemic are irreducible and epistemically valuable” (Grebowicz, 2005).

So, as Grebowicz, Haraway and others suggest, we need to be wary of the search for "truer", consensual, universal stories of science. In Le Guin's terms, what we need is a clutch of carrierbag storytellers, not feminist heroes of a consensual tale about a renewed, democratic, inclusive science. Life is just the kind of story "bag-lady” storytellers like Haraway and Le Guin enjoy: a story of science, of life, of the "body politic" which offers no salvation or easy resolution, where no-one (or thing) is a hero - not Anna, not Spence, not TY, not even feminism/s. A good starting point, then for a "dissensual critique-model” of feminist science studies would be one which encompasses different stories - both theoretical and fictional - which together might alter who and what is at stake in the narrative field of science. That is, both the stories of science told by the likes of Haraway, and those told by SF writers such as Jones.

\section{References}

Aitken, R. John \& Graves, Jennifer A. Marshall (2002). The future of sex. Nature, 415, 963. 
Bainbridge, David (2003). The $X$ in sex: How the $X$ chromosome controls our lives. Cambridge, MA: Harvard University Press.

Barad, Karen (2003). Posthumanist performativity: Toward an understanding of how matter comes to matter. Signs: Journal of Women in Culture and Society, 28 (3), 801-31.

Barr, Marleen S. (1987). Alien to femininity: Speculative fiction and feminist theory. Westport: Conn.: Greenwood Press.

Barr, Marleen S. (Ed.) (2000). Future females, the next generation: New voices and velocities in feminist science fiction criticism. Lanham, Md.: Rowman \& Littlefield.

Donawerth, Jane (1990). Utopian science: Contemporary feminist science theory and science fiction by women. NWSA Journal, 2 (4), 535-57.

Donawerth, Jane (1994). Science fiction by women in the early pulps, 1926-1930. In Jane Donawerth \& Carol A. Kolmerton (Eds.), Utopian and science fiction by women: Worlds of difference (pp. 137-52). Liverpool: Liverpool University Press.

Donawerth, Jane (1997). Frankenstein's daughters: Women writing science fiction. New York: Syracuse University Press.

Fausto-Sterling, Anne (2001). Life in the xy corral. In Muriel Lederman \& Ingrid Bartsch (Eds.), The gender and science reader (pp. 234-51). New York: Routledge.

Fausto-Sterling, Anne (2005). The bare bones of sex: Part 1—sex and gender. Signs, 30 (2), 1491-1527.

Graves, Jennifer A. Marshall (2002). The rise and fall of SRY. Trends in Genetics, 18 (5), 25964. 
Grebowicz, Margret (2005). Consensus, dissensus, and democracy: What is at stake in feminist science studies? Philosophy of Science: Proceedings of the PSA 2004. < http://philsciarchive.pitt.edu/archive/00001946/>

Haraway, Donna (1986). Primatology is politics by other means. In Ruth Bleier (Ed.), Feminist approaches to science (pp. 77-118). New York: Pergamon.

Haraway, Donna (1989). Primate visions: gender, Race and nature in the world of modern science. New York \& London: Routledge.

Haraway, Donna (1991). Simians, cyborgs and women: The reinvention of nature. New York \& London: Routledge.

Haraway, Donna (1992). The promises of monsters: A regenerative politics for inappropriate/d others. In Lawrence Grossberg, Cary Nelson \& Paula A. Treichler (Eds.), Cultural Studies (pp. 295-337). New York: Routledge.

Haraway, Donna (1995). Otherworldly conversations, terran topics, local terms. In Vandana Shiva \& Ingunn Moser (Eds.), Biopolitics: A feminist and ecological reader on biotechnology (pp.69-92). London: Zed Books.

Hird, Myra (2003). From the culture of matter to the matter of culture: Feminist explorations of nature and science. Sociological Research Online, 8 (1). $<$ http://www.socresonline.org.uk/8/1/hird.html>

Hird, Myra (2004a). Sex, gender, and science. New York: Palgrave Macmillan.

Hird, Myra (2004b). Feminist matters: New materialist considerations of sexual difference. Feminist Theory, 5 (2), 223-32. 
Hollinger, Veronica (2006). "Prefutural tension": Gwyneth Jones's gradual apocalypse. In Justine Larbarlestier (Ed.), Daughters of earth: Feminist science fiction in the Twentieth Century (pp. 326-339). Middletown, CT.: Wesleyan University Press.

Jones, Gwyneth (1999). Deconstructing the starships: Science, fiction, and reality. Liverpool: Liverpool University Press.

Jones, Gwyneth (2004). Life. Seattle, WA: Aqueduct Press.

Jones, Gwyneth (2005a). Life, aqueduct press and 'alt' flame wars. Bold as love. Blog entry, January 2. <Http://homepage.ntlworld.com/gwynethann/mtblog2005.htm>

Jones, Gwyneth (2005b). Panel discussion: Gwyneth Jones's Life: Feminist challenge or challenge to today's feminists? Wiscon 29, May 27-30, Madison, (transcript available at http://coffeeandink.livejournal.com/459209.html)

Jones, Gwyneth (2007). Shora. Bold as love. Blog entry, March 27. $<$ http://blog.boldaslove.co.uk?P=122/>

Jones, Gwyneth (2008). True life science fiction: Sexual politics and the lab procedural. In Beatriz da Costa \& Kavita Philip (Eds.) Tactical biopolitics: Art, activism, and technoscience (pp. 289-306). Cambridge MA.: MIT Press.

Jones, Steve (2003). Y: The descent of men. Boston: Houghton Mifflin.

Keller, Evelyn Fox (1983). A feeling for the organism: The life and work of Barbara McClintock. San Fransisco: W.H. Freeman.

Keller, Evelyn Fox (1985). Reflections on gender and science. New Haven, Conn.: Yale University Press. 
Kirby, Vicki (2001). Quantum anthropologies. in Laurence Simmons \& Heather Worth (Eds), Derrida downunder (pp. 53-68). Palmerston North: Dunmore Press.

Kirby, Vicki (2008). Subject to natural law: A meditation on the 'two cultures' problem. Australian Feminist Studies, 23 (55), 5-17.

Lefanu, Sarah (1988). In the chinks of the world machine: Feminism and science fiction. London: The Women's Press.

Longino, Helen (2002). The fate of knowledge. Princeton: Princeton University Press.

Mackenzie, Adrian \& Murphie, Andrew (2008). The two cultures become multiple? Australian Feminist Studies, 23 (55), 87-100.

Margulis, Lynn \& Sagan, Dorion (1997). What is sex? New York: Simon and Schuster.

Pilinovsky, Helen (Ed.) (2005). Third annual wiscon issue. Special issue of Extrapolation, 46 (1).

Roberts, Celia (2000). Biological Behaviour? Hormones, Psychology, and Sex. NWSA Journal, $12(3), 1-20$.

Roberts, Celia \& Mackenzie, Adrian (2008). Science. Theory Culture \& Society, 23 (2-3), 15763.

Roberts, Robin (1993). A new species: Gender and science in science fiction. Urbana: Illinois University Press.

Rose, Hilary (1986). Beyond masculinist realities: A feminist epistemology for the sciences. In Ruth Bleier (Ed.), Feminist approaches to science (pp. 57-76). New York: Pergamon Press.

Rose, Hilary (1988). Comment on Schiebinger's "The history and philosophy of women in science: A review essay". Signs, 13 (2), 377-80. 
Rose, Hilary (1994). Love, power and knowledge: Towards a feminist transformation of the sciences. Cambridge: Polity Press.

Rose, Hilary (1996). My enemy’s enemy is - only perhaps - my friend. In Andrew Ross (Ed.), Science wars (pp.80-101). Durham: Duke University Press.

Roy, Deboleena (2004). Feminist theory in science: Working toward a practical transformation. Hypatia, 19 (1), 255-79.

Schiebinger, Londa (2001). Has feminism changed science? Cambridge, Mass.: Harvard University Press.

Schneider, Joseph (2005). Donna Haraway: Live theory. London: Continuum.

Severin, Laura \& Wyer, Mary (2000). The science and politics of the search for sex differences: Editorial. NWSA Journal, 12 (3), vii-xvi.

Short, Roger V. \& Balaban, Evan (Eds.) (1994). The Differences between the sexes. Cambridge: Cambridge University Press.

Spanier, Bonnie (2001). Foundations for a "new biology". In Muriel Lederman \& Ingrid Bartsch (Eds.), The gender and science reader (pp. 272-88). London: Routledge.

Squier, Susan \& Littlefield, Melissa M. (Eds.) (2004). Feminist theory and /of science: Feminist theory special issue. Feminist Theory, 5 (2), 123-26.

Sykes, Bryan (2003). Adam's curse: A future without men. London: Bantam Press.

Wayne, Marta L. (2000). Walking a tightrope: The feminist life of a Drosophila biologist. NWSA Journal, 12 (3), 139-50.

Weasel, Lisa H. (1997). The cell in relation: An ecofeminist revision of cell and molecular biology. Women's Studies International Forum, 20 (1), 49-59. 
Weasel, Lisa H. (2001). Dismantling the self/other dichotomy in science: Towards a feminist model of the immune system. Hypatia, 16 (1), 27-44.

Williams, Tess (2007). Embodying change: (R)evolutionary theories of an alien synthesis. In Margret Grebowicz (Ed.), scifi in the mind's eye: Reading science through science fiction (pp. 115-36). Chicago: Open Court.

Wilson, Elizabeth (1998). Neural geographies: Feminism and the microstructure of cognition. New York: Routledge.

Wilson, Elizabeth (1999). Introduction: Somatic compliance - feminism, biology and science. Australian Feminist Studies, 14 (29), 7-18.

Wolmark, Jenny (1993). Aliens and others: Science fiction, feminism and postmodernism. Hemel Hempsted: Harvester Wheatsheaf.

\section{Notes}

1 Key book-length studies of feminist SF include Barr (1987); Lefanu (1988); Roberts (1993); and Wolmark (1993). More recent overviews of feminist SF criticism can be sampled in Barr 2000 and Pilinovsky 2005. One of the few critics to consider the role of science in women's SF is Jane Donawerth $(1990 ; 1997)$.

${ }^{2}$ Her first novel was fantasy, published in 1977. Jones has published 19 novels and three short story collections, and also written over 20 books for young adults under the name Anne Halam. A noted SF critic and reviewer, some of her critical pieces are collected in Deconstructing the Starships (1999). More information can be found at http://homepage.ntlworld.com/gwynethann/index.html.

3 Jones vividly describes her encounter with Margulis’s work: “Drawn by her reputation among feminists, I had encountered Lynn Margulis’s endosymbiotic theory, and her stubborn fight to break own the establishment's resistance - on point of doctrine completely innocent to lay-persons, yet immediately recognised by the priesthood as a challenge that shook the pillars of the universe” (2008, p.5).

4 I borrow this term from Celia Roberts: "Whilst feminist theorists have successfully argued that the biological cannot be directly approached, we need effective ways of thinking through these historically powerful roles. To focus on the co-construction or 'interimplication' of the biological and the social, rather than replicating their division, may prove fruitful” (Roberts, 2000, p.17). 
${ }^{6}$ See for example recent books such as Jones Y: The Descent of Men; Sykes, Adam's Curse: A Future Without Men and Bainbridge The $X$ in Sex, all published in 2003, prompting Jennifer Marshall Graves (Professor in Comparative Genomics) to dub it "the Year of the Sex Chromosomes" (2004, p.99). Although published shortly afterwards, Jones actually started writing Life in 1995, and had difficulties in keeping up with developments in the life sciences at this time: "I had a devil of a job trying to wind away with the science of the $\mathrm{Y}$ chromosome in a way that would not be contradicted before the book got published” (2005b). See also Aitken \& Graves (2002) and Graves (2002).

7 Which, as Jones notes, is also reflected in the depoliticisation of "gender studies": "in the academic world sexual politics was showing a strong drift away from terms like 'Women's Studies' or 'Feminism', towards the less confrontational 'Gender Studies'. (There was money in it! You got more funding if you agreed to drop the words Women and Feminism from course titles)" (2007).

8 See also Grebowicz (2005) and Hird who seeks to “undermine the sex/gender binary ... by challenging 'sex', we challenge not only assumptions about 'gender' but the binary itself” (2004, p.152). 